\title{
Effect of Mercedes model with embedded assessment strategy and technology on the learning outcomes of biology students in Lagos Nigeria.
}

\author{
Adenike Julianah Oladipo ${ }^{1}$, Olusoji Olurotimi Adewumi ${ }^{1}$, and Akinleye Oluyemi Ogundiwin ${ }^{2}$ \\ ${ }^{1}$ Department of Science Education, Distance Learning Institute, University of Lagos, Nigeria \\ ${ }^{2}$ Department of Science Education, Faculty of Education, National Open University of Nigeria \\ Corresponding author contact: adenikeoladipo@gmail.com
}

\begin{abstract}
This study examines the effect of Mercedes Model with Embedded Assessment Strategy and Technology on students' learning outcomes in Biology. It is a quasi-experimental study which has adopted a pre-test and a post-test control group design. Four hypotheses guided the study. 568 senior secondary class I biology students from 6 randomly selected schools formed the sample size. Three instruments, namely Mercedes Model with Embedded Assessment Strategy and Technology in Diffusion and Osmosis ( $M^{2} E A S T I D$ and $\left.M^{2} E A S T I O\right)$, Conventional Lesson Plan on Diffusion and Osmosis (COLPOD and COLPO), and Test on Students' Learning Outcomes in Osmosis and Diffusion (TOSLO $\left.{ }^{2} D\right)$ were used to generate data for the study. Frequency counts, means, deviation and analysis of covariance were used to analyze the data. The results indisputably suggest that there is a significant effect on students' learning outcomes and their understanding of fundamental biological concepts. Considered should also be the decisive effect of the subject specialization on the dependent measurable characteristics. Mercedes Model with Embedded Assessment Strategies and Technology therefore, proved to be effective and efficient in significantly improving the students' learning outcomes. Hence, it is highly recommended that biology teachers in senior secondary schools adopt and integrate Mercedes Model with Embedded Assessment Strategy and Technology into their teaching programmes for understanding and application of biology concepts.
\end{abstract}

Keywords: Mercedes Model with Embedded Assessment Strategy and Technology, subject specialization, osmosis, diffusion, learning outcomes.

\section{Introduction}

Biology is the science of life. With the increasing challenges facing our world, the science of Biology enables us to understand it. However, students' difficulties in learning biology have been studied by several researchers (Johnstone \& Mahmoud, 1980; Tolman, 1982; Jennison \& Reiss, 1991; Lazarowitz \& Penso, 1992, Odom \& Barrow, 2007; Fisher \& Lineback, 2011, and Oladipo \& Ihemedu, 2018). Moreover, researchers in science education have observed low outcomes by Biology students especially in abstract concepts (Odom \& Barrow 1995; Zuckerman 1998; Christianson \& Fisher 1999; Udeani, 2002; She 2004; Oladipo 2009; Fisher, Williams \& Lineback 2011; Oztas 2014). Similar reports released from West African Examinations Council (WAEC) Chief Examiners' Reports (2000, 2003, 2005, 2006, 2012 and 2015) revealed the poor performance of students in cell and environment/transport in animal and plant, ecology, genetics aspects of biology.

The most popular factor identified as militating against students' attainment of the objectives of Science curriculum is the unsuitable and uninspiring teaching methods and strategies adopted by Science teachers (Welch, 1985; Martin \&Ramsden, 1986; Biggs, 1988; Iroegbu, 1998; Baron, 2000, Oladipo, 2009 and Ogundiwin, 2013). In addition to this factor, is the lack of utilization or integration of technology in the teaching and learning of science in the Senior Secondary School (Howie \& Blignaut, 2000; Ahmed,2008; Draper, 2010). Hence, research effort in science education has centered on the improvement of instructional methods and strategies as a way of proffering solution to the recurring low performance in science subjects in general and Biology in particular, (Ajewole, 1994, Akubuilo, 1995; James \& Shaibu 1997, Esiobu, 2000, Gallagher, 2000, Oladipo 2009, Ogundiwin \& Oladipo 2018). Besides, only few researchers have evaluated the effectiveness of teaching activities in the classroom (Lawson, 1988; Glordan, 1996, Gallagher, 2000, Oladipo 2009). There is an urgent need 
therefore, for a teaching method and/ or strategy that will improve students' learning and also emphasize the process of arriving at an answer rather than simply requiring students to regurgitate the "right" answer, whether or not they understand either the answer or its justification (Gallagher, 2000).

In the quest for a solution to the inadequate teaching methods and strategies employed by science teachers, Gallagher (2000), after exploring various theoretical models of teaching and learning, devised a model which prepares and allows teachers to teach basic scientific concepts for understanding and application. He named the model 'Mercedes Model' because it has three compartments which focus on building a knowledge base (acquisition of factual information), generating understanding (making sense of information and making connections between new information and students' existing ideas), and finding application (making connection between concepts and the real-world experience) respectively. (Fig. 1).

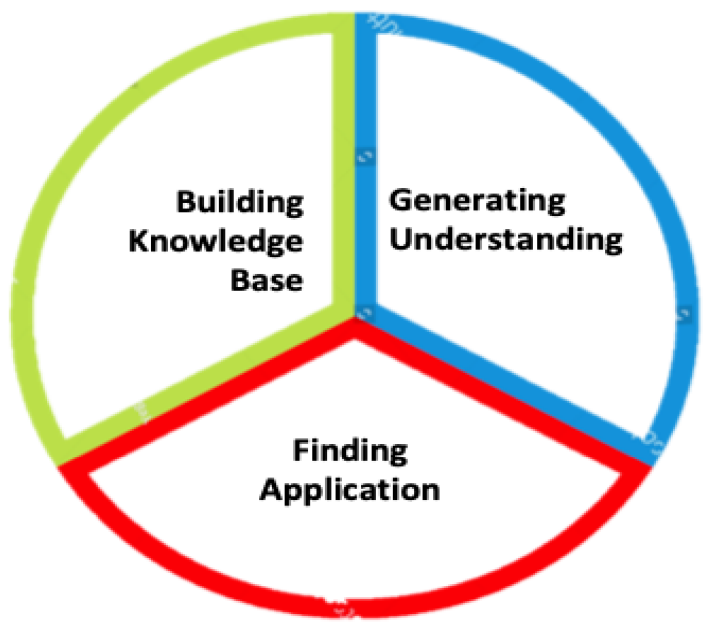

Fig. 1: Mercedes Model (MM)

A distinctive feature of this model is that each of the three compartments as shown in Fig. 1 demands different pedagogic/assessment strategies. Gallagher (2000) therefore, asserted that for the Mercedes Model to be an effective model of instruction an overlay of continuous formative, embedded assessment should be added (Fig.1).

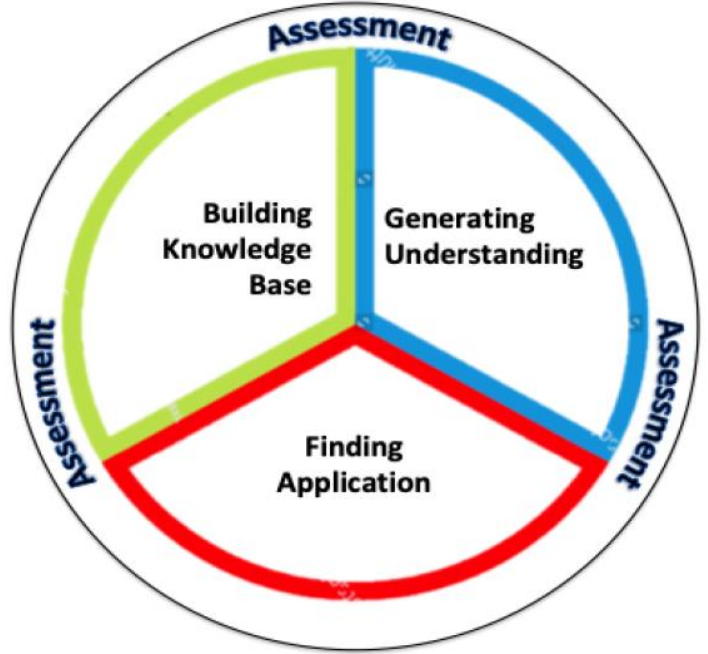

Fig. 2: Mercedes Model with Embedded Assessment Strategy (MMEAS)

Similarly, Oladipo (2018), reflecting on the current trends in educational reforms towards the inclusion of technology in driving education, concluded that Mercedes Model with Embedded Assessment Strategy should be upgraded to embrace technology. That is how technology was 
integrated into the three compartments of Mercedes Model with embedded assessment strategy in a ratio of 30:40:30 respectively. It should be noted, however, that the suggested ratio was obtained from thorough studies into the Science curriculum and objectives of teaching science in senior secondary school. A full description of the proposed Mercedes Model with Embedded Assessment Strategy and Technology $\left(\mathrm{M}^{2} \mathrm{EAST}\right)$ is provided in the figure below.

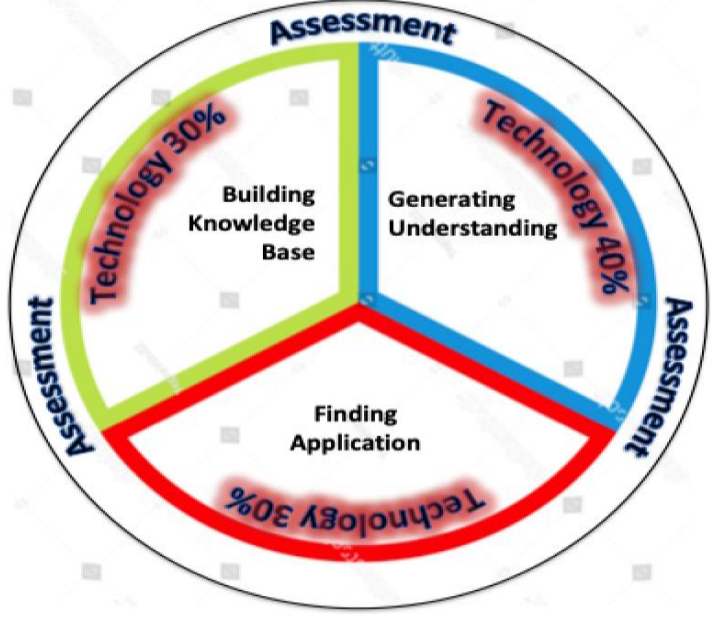

Fig.3: Mercedes Model with Embedded Assessment Strategy and Technology (M²EAST)

What is more, a strong canon has been built up in research on gender issue in the science classroom for over five decades now. This is as a result of reasonable worries about the gross underrepresentation of girls and the number and contribution of women in science and technology disciplines. A series of gender disparities in education have been exposed (Abagi 1997; FAWE 1997; Udeani, 2002; Rathgeber 2009; Ekine 2010), which, in turn, has made it necessary to probe further if the achievement gap has been narrowed. Another very important factor that determines students' learning outcomes is subject specialization. For instance, science students and their non-science counterparts have different ability levels. However, in Lagos State, it is expected of senior secondary students to do a course in Biology irrespective of their class type. This is another reason why the proposed study investigates further into the effect of subject specialization on students' learning outcomes using $\mathrm{M}^{2}$ EAST to teach Biology.

Biology is a major subject required for admission into tertiary institutions for professional courses in medicine and biological sciences. Repeated reports of unsatisfactory performance in biology at Senior Secondary Certificate Examination have raised deep concern among the respective science educators, researchers and school stakeholders. Larger Biology classes stem from the fact that more students still offer Biology as the only science subject and may not encounter science again after secondary school level calls for an urgent intervention. Hence, the need to find ways and means of motivating students to derive maximum benefit from the teaching of Biology. A systematic and innovative instructional and assessment strategy integrated with technology that could improve the scenario is therefore necessary. Accordingly, the purpose of the present study is to analyze the effect of Mercedes Model with Embedded Assessment Strategy and Technology on biology students' learning outcomes in Lagos State, Nigeria.

\subsection{Theoretical Framework}

The current research develops from the constructivist theory. And the constructivist theory of learning, as is widely known, views learning as an adaptive process, in which learners' conceptual schemes are progressively reconstructed so that they keep up with a wider range of experiences and ideas. It is also seen as an active process of sense making over which the learner has some control. Constructivism is an approach in education and science asserting that knowledge is a justified belief and can be constructed and reconstructed by the individual themselves from their experiences, 
observations and social interactions to facilitate the process of understanding and meaningful learning experience. In a more comprehensive way, constructivism can be viewed, as a theory of meaning making, knowledge construction and reconstruction that fosters conceptual understanding and which provides insight on how learners move along the pathway of their own worldview to scientific viewpoints using socio-cognitive anchors.

\subsection{Research Hypotheses}

Four null hypotheses were tested at 0.05 level of significance.

1. There is no significant difference in students' learning outcomes in Biology concepts after exposure to the Mercedes Model with Embedded Assessment Strategy and Technology or in the control group.

2. The main effect of subject specialization (science and non-science) on students' learning outcomes in Biology concepts is not significant.

3. There are non-significant main effects of gender (female and male) on students' learning outcomes in Biology concepts.

4. There are non-significant interaction effects of subject specialization (science and non-science) and gender (female and male) on students' learning outcomes in Biology concepts.

\section{$2 \quad$ Methodology}

The study adopted a pretest-posttest control group quasi-experimental research design. The variables in this study include the independent variable which is an instructional strategy at two levels; namely Mercedes Model with Embedded Assessment Strategy and Technology (M $\left.{ }^{2} E A S T\right)$ in biology and Conventional Strategy in biology, the moderating variables which consist of subject specialization (Science/ Non Science) and gender (Male/ Female) while the dependent variables include Test on Students' Learning Outcomes in Osmosis and Diffusion (TESLO $\left.{ }^{2} \mathrm{D}\right)$.

\subsection{Sample and Sampling Technique}

Two out of the six Education Districts (EDs) in Lagos State were purposively selected based on the criterion that the two EDs were far away from each other to avoid the problem of contamination. Three senior secondary schools were purposively selected from each ED as to the availability of projector, white board or screen, generator, at least two graduate biology teachers, fairly wellequipped biology laboratories, evidence of students' performance in the Senior Secondary Certificate Examination (SSCE) for at least five years, being a public co-educational secondary school and willingness on the part of the teachers to participate in the study. In total, six schools from the two selected EDs took place in the study. Two intact classes (one science and another non-science) were randomly selected from each of the six schools amounting to12 intact classes altogether. Twelve biology teachers have taken part in the study. The two EDs were randomly assigned to treatment such that one was the experimental group and the other one- the control group. Students in the Senior Secondary class I (SS I) were involved in the study. First preference was given to SS I students who having been exposed to some basic biological concepts and skills had managed to obtain the required background in biology and were considered appropriate for the study. Besides, these students were more likely to put all their time in the experiment (teaching) since they were not preparing for any external examination. The total number of students involved in the study was 568 and the study lasted for 6 weeks.

\subsection{Choice of Course Content}

The course content on diffusion and osmosis as topics for this study was chosen pursuant to the guidelines released in WAEC Chief Examiners' Reports (2000, 2003, 2005, 2006,2012, 2015) on the poor performance of students in cell and environment/transport in animal and plant aspects of biology. 
Similarly, an examination of the biology SSCE syllabus and scheme of work showed that the students were just about to start the lesson on cell and its environment.

\subsection{Research Instruments}

The study was conducted with the benefit of three instruments which were later modified within the context of the research objectives. These three specific instruments were as follows:

1. Mercedes Model with the Embedded Assessment Strategy and Technology in Diffusion and Osmosis ( $\mathrm{M}^{2}$ EASTID and $\mathrm{M}^{2}$ EASTIO) and Teacher's Instructional Guide for Mercedes Model with Embedded Assessment Strategy in Diffusion and Osmosis (Tig. M²EASTID and Tig. $\mathrm{M}^{2}$ EASTIO).

2. Conventional Lesson Plan on Diffusion and Osmosis (COLPOD and COLPO) and Teacher's Instructional Guide for Conventional Lesson on Diffusion and Osmosis.

3. Test on Students' Achievement in Osmosis and Diffusion $\left(\right.$ TESLO $\left.^{2} \mathrm{D}\right)$

\subsubsection{Mercedes Model with Embedded Assessment Strategy and Technology in Diffusion (M2 EASTID) and Mercedes Model with Embedded Assessment Strategy and Technology in Osmosis (M2 EASTIO).}

These instruments are treatment or instructional packages developed by the researcher to teach students diffusion and Osmosis. They were based on the principles of the Mercedes Model and the Embedded Assessment Strategy of Gallagher (2000) and contained the basic elements of every lesson plan including topic, duration, instructional objectives, previous knowledge, reference and procedural steps. However, the procedural steps comprise the three Mercedes Model components which deal with building concrete knowledge base, generating understanding and finding the appropriate application of that base - hereto, diffusion and osmosis. Each component consists of five teaching/assessment strategies selected from the thirteen strategies identified by Gallagher. These five questions per each component on each of the topics of diffusion and osmosis are to be answered by the students as the instruction proceeds. The five teaching/assessment strategies selected from the thirteen strategies identified by Gallagher were selected according to the relevance and appropriateness of the strategies for the teaching of diffusion and osmosis. These five strategies include:
$\mathrm{S}_{1}$ - mind stretcher
$\mathrm{S}_{2}$ - models, pictures and diagram
$\mathrm{S}_{3}$ - preposition generation
$\mathrm{S}_{4}$ - Laboratory demonstration
$\mathrm{S}_{5}$ - Laboratory experiment/record observation.

\subsubsection{Teachers' Instructional Guide for Mercedes Model with Embedded Assessment Strategy and Technology in Diffusion (TIG. M2 EASTID) and Mercedes Model with Embedded Assessment Strategy and Technology in Osmosis (TIG. M2 EASTIO).}

TIG.M ${ }^{2}$ EASTID and TIG.M ${ }^{2}$ EASTIO are instructional guides for the treatment group (experimental) on diffusion and osmosis. They constitute the basic procedural steps in a typical lesson plan, such as: topic, duration, instructional objectives, previous knowledge, reference and procedural steps. In addition, when discussing the procedural steps, it should be borne in mind that they involve the three components of the Mercedes Model, namely: Building knowledge base, Generating understanding and Finding application. Each section embraces five teaching/assessment strategies selected from the thirteen strategies identified by Gallagher. Unlike $\mathrm{M}^{2} \mathrm{EASTID}$ and $\mathrm{M}^{2} \mathrm{EASTIO}$, TIG.M ${ }^{2}$ EASTID and TIG.M ${ }^{2}$ EASTIO contain embedded questions and answers on diffusion and osmosis. Each component of the Mercedes Model with Embedded Assessment Strategy and Technology was carefully integrated into the school biology time-table adding up to three double periods per week, totaling 12 contact periods for both diffusion and osmosis in two weeks. 


\subsubsection{Instructional Procedure Components at 3 levels for 80minutes/2periods for} TIG.M2EASTID and TIG.MEASTIO

\section{Building Knowledge Base}

1. Review previous lesson using any of the 13 teaching/assessment strategies.

2. Stimulate students' interest using any relevant resources/technology (attention grabber)

3. Introduce the concept and assess students' background knowledge about the concept.

4. Build Knowledge base using technology (PowerPoint)

5. Emphasize key vocabulary

6. Checkpoint (using one of the 13 teaching/assessment strategies).

7. Enrich Knowledge base using Technology (simulation, PowerPoint).

8. Checkpoint (using one of the 13 teaching/assessment strategies).

9. Summarize

10. Checkpoint (using one of the 13 teaching/assessment strategies).

\section{Generating Understanding}

1. Engage students in demonstration.

2. Checkpoint (using one of the 13 teaching/assessment strategies)

3. Generate understanding using technology (virtual labs, video clips, simulation, or audio)

4. Checkpoint (using one of the 13 teaching/assessment strategies).

5. Assign students for group practice

6. Checkpoint (using one of the 13 teaching/assessment strategies).

7. Summarize/Reflection

8. Checkpoint (using one of the 13 teaching/assessment strategies).

\section{Finding Application}

1. Guide student to reason on application of lesson

2. Use technology to find available applications (video clips)

3. Checkpoint (using one of the 13 teaching/assessment strategies).

4. Critical Thinking session. Divide students into groups to further find application/group work

5. Checkpoint (using one of the 13 teaching/assessment strategies).

6. Summarize/Reflection

\subsubsection{Conventional Lesson Plans on Diffusion and Osmosis COLPOD and COLPO}

These instruments were developed in accordance with the typical steps of a conventional lecture method of instruction, i.e. topic, objectives of each lesson stated in behavioral or instructional manner, previous knowledge, materials, references, introduction, procedures/presentation, evaluation and assignment. All in all, the preparation of the lesson plans was carried out in strict adherence to the steps listed above. On the whole, there were twelve contact periods on the concept of diffusion and osmosis. The time allotted to each contact period was 40 minutes on the school's time-table totaling 80 minutes per day. The instructional procedure involved introduction to concepts, description, discussion and questions. The students were provided with a brief summary of the main ideas to be discussed along with a set of assigned tasks. The instructional periods lasted for two weeks.

\subsubsection{The procedures for Conventional Lesson Plans are similar to the lecture method.}

Each lesson is presented in the form of a lecture.

- The teacher presents the lesson in the form of a lecture

- Teacher writes the topic for the lesson on the chalkboard

- Teacher states the objectives for the lesson

- Teacher outlines the content of the topic on the chalkboard 
- Teacher explains the content, making use of the information provided by the researcher in handling each topic

- Students listen to the teacher and write down chalkboard summary.

- The Teacher allows students ask questions on areas of the topic that are not clear to them.

- Teacher answers the students questions

- Teacher summaries the lesson

- Teacher gives students home assignment

\subsubsection{Test on Students' learning outcomes in Osmosis and Diffusion (TESLO2D)}

This test was designed to measure students' learning outcomes in diffusion and osmosis based on the three compartments of the Mercedes Models. Each compartment consists of five embedded questions on five assessment strategies out of the thirteen identified by Gallagher. In all, there are thirty questions. The table of specification for the construction of TESLO' ${ }^{2} \mathbf{D}$ is presented in Table 1

Table 1: Table of Specification. Table of Specification for TESAOD

\begin{tabular}{|l|l|l|l|l|l|l|l|}
\hline \multicolumn{8}{|c|}{ Strategies } \\
\hline Topic & Components & $\mathbf{S}_{\mathbf{1}}$ & $\mathbf{S}_{\mathbf{2}}$ & $\mathbf{S}_{\mathbf{3}}$ & $\mathbf{S}_{\mathbf{4}}$ & $\mathbf{S}_{\mathbf{5}}$ & Total \\
\hline Diffusion & Knowledge & $1(3)$ & $1(4)$ & $1(1)$ & $1(5)$ & $1(2)$ & 5 \\
& Understanding & $1(2)$ & $1(2)$ & $1(5)$ & $1(1)$ & $1(3)$ & 5 \\
& Application & $1(4)$ & $1(1)$ & $1(2)$ & $1(5)$ & $1(3)$ & 5 \\
\hline Osmosis & Knowledge & $1(3)$ & $1(1 \mathrm{a}, \mathrm{b}, \mathrm{c})$ & $1(2)$ & $1(4)$ & $1(5)$ & 5 \\
& Understanding & $1(4)$ & $1(2)$ & $1(3)$ & $1(1 \mathrm{a}, \mathrm{b}, \mathrm{c})$ & $1(5)$ & 5 \\
& Application & $1(1 \mathrm{a}, \mathrm{b}, \mathrm{c})$ & $1(3)$ & $1(4)$ & $1(2)$ & $1(5 \mathrm{a}, \mathrm{b}, \mathrm{c})$ & 5 \\
\hline Total & & $\mathbf{6}$ & $\mathbf{6}$ & $\mathbf{6}$ & $\mathbf{6}$ & $\mathbf{6}$ & $\mathbf{3 0}$ \\
\hline
\end{tabular}

Figures in parentheses are item numbers

\subsection{Refinement and Validation of Instruments}

\subsubsection{Validation of M2EASTID, M2EASTIO, TIG.M2EASTID, and TIG.M2EASIO}

Copies of $\mathrm{M}^{2} E A S T I D$ and $M^{2} E A S T I O$ were developed, produced and given to three experts in curriculum development, test measurement and four experienced secondary school biology teachers who were WAEC chief examiners to comment, advice and correct the areas of ambiguity and suggest areas to be improved upon. This is to certify that these instruments are suitable in terms of language, clarity, breadth and class. The face validated instruments were administered on senior secondary students I (SS I) of a school that did not participate in the main study. Results obtained were used to establish the reliability and internal consistency of the items. The Cronbach alpha value of 0.74 was obtained for the 42 items, some of which have negative item total correlations. 12 of such items were removed leaving a total of 30 items with Cronbach coefficient of 0.78 . Based on these results, new drafts were made and tried out on a pilot programme. Taking everything into consideration, it can be inferred that the findings and observations on the pilot programme enhanced the final adjustment of the instruments.

\subsubsection{Validation of COLPOD and COLPO}

Four experienced teachers that have taught biology for well over 10 years at the senior secondary school levels were asked to offer their expert advice on the suitability of the adopted instruments. Their suggestions and critical assessment helped improve the final adjustments to the instruments described above.

\subsubsection{Validation of TESLO2D}

First, copies of TESLO ${ }^{2} \mathrm{D}$ were given out to the experts in biology education and biology teachers in senior secondary schools for scrutiny both in terms of content and coverage. Moreover, the language and construct validity were ensured by sampling language experts and test construction 
experts. The draft test was administered on forty senior secondary class I students to measure reliability. A couple of weeks later, the test was administered to the same set of students. The responses obtained were used to ascertain the test - re-test reliability coefficient which was 0.74 with an average item difficulty of 0.47 .

\subsubsection{The procedure for data collection and data analysis}

TESLO $^{2} \mathrm{D}$ was administered to all the students in both experimental and control group during the first week. It took 2 weeks to process the results. TESLO ${ }^{2} \mathrm{D}$ was administered to both the control and experimental groups on the fourth weeks. TESLO ${ }^{2} \mathrm{D}$ was scored manually by the researcher as follows: for each item, students earn two points for each correct response on TESLO ${ }^{2} \mathrm{D}$, and zero points for each incorrect response. The response of each student in each concept was summed up separately. The range of obtainable total scores vary from zero (0) to thirty (30) making a total of 60 points for TESLO ${ }^{2} \mathrm{D}$. For each of the scores obtained by the students, the percentage was computed and used for data analysis. The collected data was analyzed with the help of both descriptive and inferential statistics. The descriptive statistics include frequency counts and means in addition to the analysis of covariance (ANCOVA) as a method of comparing the results obtained on different sets of data. The Estimated marginal mean was used to produce the relevant descriptive table of the groups.

\section{$3 \quad$ Results}

\subsection{Descriptive Statistics associated with treatment, control, gender and subject specialization}

Table 2: Summary of descriptive statistics associated with treatment, control, gender and subject specialization

\begin{tabular}{|l|c|c|c|c|c|c|}
\hline & \multirow{2}{*}{ MERCEDES } & CONVENTIONAL & \multicolumn{2}{|c|}{ SUBJECT } & \multicolumn{2}{c|}{ GPECIALISATION } \\
\cline { 4 - 7 } & & SCIENCE & $\begin{array}{c}\text { NON- } \\
\text { SCIENCE }\end{array}$ & FEMALE & MALE \\
\hline $\begin{array}{l}\text { Noof } \\
\text { cases }\end{array}$ & 286 & 282 & 303 & 265 & 283 & 285 \\
\hline $\begin{array}{l}\text { Pre-test } \\
\text { mean }\end{array}$ & 2.59 & 3.44 & 5.95 & 1.26 & 4.95 & 2.26 \\
\hline $\begin{array}{l}\text { Pre-test } \\
\text { S.D }\end{array}$ & 1.18 & 0.66 & 1.18 & 0.96 & 1.15 & 0.95 \\
\hline $\begin{array}{l}\text { Posttest } \\
\text { mean }\end{array}$ & 15.41 & 8.64 & 16.52 & 7.37 & 16.62 & 15.47 \\
\hline $\begin{array}{l}\text { Posttest } \\
\text { S.D }\end{array}$ & 1.13 & 0.46 & 1.19 & 0.76 & 1.19 & 0.76 \\
\hline $\begin{array}{l}\text { Mean } \\
\text { Gain }\end{array}$ & 12.82 & 5.20 & 10.57 & 6.11 & 11.67 & 13.21 \\
\hline
\end{tabular}

Table 2 displays the descriptive statistics of the students' learning outcomes. The post test scores improved for Mercedes Model with Embedded Assessment and Technology, Conventional strategy Science, Non science, Female and male in achievement scores with 12.82, 5.20, 10.57, 6.11,11.67 and 13.21, respectively.

The posttest scores improved for Mercedes Model with Embedded Assessment and Technology in achievement scores by 12.82. (Pretest mean $=2.59$, Posttest mean $=15.41$ ). In the case of conventional strategy, the posttest scores improve in achievement by 5.20 (Pretest mean $=3.44$, Posttest mean $=$ 8.64). The posttest scores improved for Science students in achievement scores by 10.57. (Pretest mean $=5.95$, Posttest mean $=16.52$ ), In the case of Non science, the posttest scores improve in achievement by 6.11 (Pretest mean $=1.26$, Posttest mean $=7.37$ ). The posttest scores improved for Female students in achievement scores by 11.57. (Pretest mean $=4.95$, Posttest mean $=16.62)$. In the 
case of the Male, the posttest scores improve in achievement by 13.21 (Pretest mean $=2.26$, Posttest mean $=15.47$ ).

\subsection{Testing the Null Hypotheses}

Ho1: There is no significant difference in students' learning outcomes in Biology concepts after exposure to the Mercedes Model with Embedded Assessment Strategy and technology or in the control group.

Table 3: Summary of Analysis of Covariance of students' learning outcomes,

Dependent Variable: Post learning outcomes

\begin{tabular}{|l|l|l|l|l|l|l|}
\hline Source & $\begin{array}{l}\text { Type III Sum of } \\
\text { Square }\end{array}$ & Df & $\begin{array}{l}\text { Mean } \\
\text { Square }\end{array}$ & F. & Sig. & $\begin{array}{l}\text { Partial Eta } \\
\text { Square }\end{array}$ \\
\hline Corrected model & 40559.784 & 24 & 1689.991 & 35.025 & 0.003 & 0.359 \\
\hline Intercept & 5182.688 & 1 & 5182.688 & 107.411 & 0.000 & 0.218 \\
\hline Knowledge pretest & 1420.316 & 1 & 1420.316 & 29.436 & 0.047 & 0.173 \\
\hline Treatment & 5839.916 & 1 & 5839.916 & 60.516 & $0.000^{*}$ & 0.205 \\
\hline Error & 10084.459 & 544 & 18.5385 & & & \\
\hline Total & 305054.000 & 567 & & & & \\
\hline Corrected Total & 50644.243 & 568 & & & & \\
\hline
\end{tabular}

R Square $=0.781$ (Adjusted R squared $=0.649)$

Table 3 reveals a significant main effect of treatment on students' learning outcomes in Biology at $\left(F_{(1,544)}=60.516 ; \mathrm{p}<0.05 ; \eta^{2}=205\right)$. Therefore, $\mathrm{Ho}_{1}$ is rejected.

Table 4: Estimated Marginal means of the Treatment, and Subject specialization on students' learning outcomes in Biology.

\begin{tabular}{|l|l|l|l|}
\hline \multicolumn{1}{|c|}{ Variables } & N & Mean & Std. Error \\
\hline Intercept & & & \\
\hline Pre- achievement score & 568 & 1.07 & - \\
\hline Post- achievement score & 568 & 15.51 & 0.61 \\
\hline Treatment & & & \\
\hline Conventional Mode & 282 & 8.64 & 1.31 \\
\hline MERCEDES & 286 & 15.41 & 0.78 \\
\hline Subject specialization & & & \\
\hline Non Science & 303 & 7.37 & 1.13 \\
\hline Science & 265 & 16.52 & 0.46 \\
Gender & & & \\
Female & 283 & 16.62 & 1.15 \\
Male & 285 & 7.47 & 1.19 \\
\hline
\end{tabular}

Table 4 reveals that those exposed to Mercedes Model with Embedded Assessment and Technology had a better achievement mean score (15.41) compared to those exposed to conventional method of instruction (8.64). This is also shown in Figure 3.

Ho2: There is no significant difference in the main effect of subject specialization (science and nonscience) on students' learning outcomes in Biology concepts. 
Table 5: Summary of Analysis of Covariance of students' learning outcomes.

Dependent Variable: Post learning outcomes

\begin{tabular}{|l|l|l|l|l|l|l|}
\hline \multicolumn{1}{|c|}{ Source } & \multicolumn{1}{|c|}{$\begin{array}{c}\text { Type III Sum of } \\
\text { Square }\end{array}$} & \multicolumn{1}{c|}{ Df } & $\begin{array}{c}\text { Mean } \\
\text { Square }\end{array}$ & \multicolumn{1}{c|}{ F. } & Sig. & $\begin{array}{c}\text { Partial Eta } \\
\text { Square }\end{array}$ \\
\hline Corrected model & 40559.784 & 24 & 1689.991 & 35.025 & 0.003 & 0.359 \\
\hline Intercept & 5182.688 & 1 & 5182.688 & 107.411 & 0.000 & 0.218 \\
\hline Knowledge pretest & 1420.316 & 1 & 1420.316 & 29.436 & 0.047 & 0.173 \\
\hline Treatment & 5839.916 & 1 & 5839.916 & 60.516 & $0.000^{*}$ & 0.205 \\
\hline Subject specialization & 1064.948 & 1 & 1064.948 & 22.011 & $0.004^{*}$ & 0.166 \\
\hline Error & 10084.459 & 544 & 18.5385 & & & \\
\hline Total & 305054.000 & 567 & & & & \\
\hline Corrected Total & 50644.243 & 568 & & & & \\
\hline
\end{tabular}

The summary of ANCOVA outlined in Table 5 indicates that subject specialization had significant main effect on students learning outcomes in Biology concepts at $\left(\mathrm{F}_{(2,544)}=22.011 ; \mathrm{p}<0.05\right.$; $)$. Therefore, $\mathrm{Ho}_{2}$ is rejected. Table 2 reveals that those students in Science groups had a better mean score (16.52) in their learning outcomes than the non-science students with mean (7.37)

Hoz: There is no significant difference in the main effect of gender (male and female) on students' learning outcomes in selected Biology concepts

Table 6: Summary of Analysis of Covariance of students' Achievement, Dependent Variable: Post learning outcomes

\begin{tabular}{|l|l|l|l|l|l|l|}
\hline \multicolumn{1}{|c|}{ Source } & $\begin{array}{c}\text { Type III Sum } \\
\text { of Square }\end{array}$ & \multicolumn{1}{c|}{ Df } & \multicolumn{1}{|c|}{ Mean Square } & F- ratio & Sig. & $\begin{array}{c}\text { Partial Eta } \\
\text { Square }\end{array}$ \\
\hline Corrected model & 40559.784 & 24 & 1689.991 & 35.025 & 0.003 & 0.359 \\
\hline Intercept & 5182.688 & 1 & 5182.688 & 107.411 & 0.000 & 0.218 \\
\hline Knowledge pretest & 1420.316 & 1 & 1420.316 & 29.436 & 0.047 & 0.173 \\
\hline Gender & 105.477 & 1 & 105.477 & 2.186 & 0.066 & 0.006 \\
\hline Error & 10084.459 & 544 & 18.5385 & & & \\
\hline Total & 305054.000 & 567 & & & & \\
\hline Corrected Total & 50644.243 & 568 & & & & \\
\hline
\end{tabular}

The summary of ANCOVA depicted in Table 6 indicates that gender had no significant main effect on the students' achievement in Biology concepts at $\left(\mathrm{F}_{(1,544)}=2.186 ; \mathrm{p}<0.05\right)$. For that reason, Ho3 is not rejected. Table 2 reveals that the female students performed better in their learning outcomes with mean score of 16.62, than their male counterparts with a mean of 15.47. The difference in their means, however, was not statistically significant.

Ho4: There is no significant interaction effect of Gender (female and male) and subject specialization (science and non-science) on the students' learning outcomes in Biology concepts

Table 7: Summary of Analysis of Covariance of students' Achievement,

Dependent Variable: Post learning outcomes

\begin{tabular}{|l|l|l|l|l|l|l|}
\hline \multicolumn{1}{|c|}{ Source } & $\begin{array}{c}\text { Type III Sum } \\
\text { of Square }\end{array}$ & \multicolumn{1}{|c|}{ Df } & $\begin{array}{c}\text { Mean } \\
\text { Square }\end{array}$ & F-ratio & Sig. & $\begin{array}{c}\text { Partial } \\
\text { Eta Square }\end{array}$ \\
\hline Corrected model & 40559.784 & 24 & 1689.991 & 35.025 & 0.003 & 0.359 \\
\hline Intercept & 5182.688 & 1 & 5182.688 & 107.411 & 0.000 & 0.218 \\
\hline Knowledge pretest & 1420.316 & 1 & 1420.316 & 29.436 & 0.047 & 0.173 \\
\hline Treatment & 5839.916 & 1 & 5839.916 & 60.516 & $0.000 *$ & 0.205 \\
\hline Subject specialization & 1064.948 & 1 & 1064.948 & 22.011 & $0.004 *$ & 0.166 \\
\hline Gender & 105.477 & 1 & 105.477 & 2.186 & 0.066 & 0.006 \\
\hline Gender * Subject specialization & 154.596 & 1 & 154.596 & 1.602 & 0.217 & 0.021 \\
\hline Error & 10084.459 & 544 & 18.5385 & & & \\
\hline Total & 305054.000 & 567 & & & & \\
\hline Corrected Total & 50644.243 & 568 & & & & \\
\hline
\end{tabular}




$$
\mathrm{R} \text { Square }=0.781 \text { (Adjusted } \mathrm{R} \text { squared }=0.649)
$$

Table 7 indicates that there is no significant interaction effect of gender (female and male) and subject specialization (science and non-science) on the students' achievement in selected Biology concepts at $\left(\mathrm{F}_{(1,544)}=1.602 ; \mathrm{p}>0.05\right)$. Accordingly, $\mathrm{Ho}_{4}$ is not rejected.

\section{Discussions}

\subsection{Effects of Treatment on students' learning outcomes in Biology}

The obtained results show significant main effects of treatment on the students' learning outcomes in Biology. These results indicate that computer assisted instruction in the form of tutorials, drill and practice modes significantly enhance the students' learning outcomes in Biology better than the conventional methods. The students in the Mercedes Model with Embedded Assessment and Technology mode performed better by obtaining the higher mean score in their learning outcomes than those in the control group (the conventional mode).

The observed significant effect of Mercedes Model with Embedded Assessment and Technology over Conventional methods can be ascribed to the complete integration between the students interactive learning with Mercedes Model with Embedded Assessment and Technology strategy facilitated by its being both a learner-centered instruction strategy and a self-directed learning strategy as well. Mercedes Model with Embedded Assessment and Technology is activity based in which active learner participation is encouraged, makes special provision for students' responses, supports extra practice and gives immediate notification of results. The learners are given some time to think through the structure of the learning tasks, proceed in accordance with their needs and interests and invariably construct their own experiences (knowledge), which, in turn, have contributed to the superiority of the Mercedes Model with Embedded Assessment and Technology mode over the conventional practice. The students in the experimental group are allowed to grasp, manipulate and observe the contents themselves whereas the students in the control group are deprived of such an opportunity which is to account for their lower achievement in Biology in comparison to the experimental groups.

The students exposed to the Mercedes Model with Embedded Assessment and Technology mode, while going through the treatment, demonstrated a lot of intuition, self-discovery, motivation, enthusiasm, deep sense of direction and self-confidence as they were fascinated with the use of Mercedes Model with Embedded Assessment and Technology. This suggests the possible reason for improved achievement in Biology that occurred among the participants in the experimental group over those in the conventional group. The research results agree with those obtained by Oguntude (2014), Abimbade (2014), Erhan \& Okan (2011) who reported a significantly improved achievement of science students using Technology- based mode of instruction in biological and physical sciences. The outcomes of the study also confirm the findings of Owusu (2010), Popoola (2011) and Okebukola, (2013) who identified the inadequacy and ineffectiveness of chalk and talk method in understanding of subject matter, criticizing poor achievement in Sciences on didactic, less-heuristic, less- activity based, more rote-learning in conventional strategies adopted in teaching the students. Muhammed (2011), Achor \& Ukwuru (2014) in their research findings on the effects of Technology driven instruction on students' achievement in science stated that Technology based instruction users learn better and faster than those receiving instruction through traditional or conventional method of teaching. The higher achievement through Mercedes Model with Embedded Assessment and Technology mode over the conventional strategy is due to the fact that Mercedes Model with Embedded Assessment and Technology allowed the integration of teacher interaction with facilities.

\subsection{Effects of subject specialization on students' Learning outcomes in Biology}

The results produced show significant main effects of the subject specialization on the students' learning outcomes in Biology. Science students performed better than their non-science counterparts. 
This finding substantiates the work of Giancarlo \& Facione (2011) who found out that science students thinking manner changed significantly in two years' time. The National Policy on Education (FME 2013) stipulates that all students at the senior secondary school must offer at least one science subject. Biology proves to be the most preferred subject and chosen by numerous science and nonscience students. Therefore, students choose biology either as one of the science subjects in addition to Chemistry and/or Physics or as the only science subject they offer.

Most of the non-science students (Arts and Commercial students) choose biology not because of the 'love' or interest for the subject but because they see it as the easiest science subject when compared with chemistry and physics because of the minimal mathematical calculation in the subject. Many students in the non-science class (Arts and Commercial) see themselves as being coerce into doing biology since the Senior Secondary Certificate Examination (SSCE) regulations stipulate that they offer one science subject. Hence, they have a mind- set of doing a subject that has no bearing with their future choice of vocation. Consequently, they attend biology classes with nonchalant attitude and end up not doing well. This supports Jobia's (1979) observation that difficulty in understanding generally appears to result not only in greater anxiety but also arouse negative feeling towards the learning tasks.

\section{$5 \quad$ Implications for Educational Practice and Recommendations}

The study shows clearly that the Mercedes Model with Embedded Assessment Strategy and Technology is more effective and efficient than the conventional one. This implies that the technology-assisted model ( ${ }^{2} \mathrm{EAST}$ ) is capable of improving students' learning outcomes of biology concepts to a very large extent. Teachers now have an additional innovative strategy which will enhance teaching, learning and assessment during the process of instruction.

The impressive performance of the science students over their non-science counterparts is very revealing. This means that science students took biology more seriously and perhaps showed more commitment in studying it than those who were not enrolled in the science classes. It becomes an issue therefore, that certain measures need to be taken by both the teachers and the government towards encouraging and making the non-science students develop a more positive attitude towards biology. In view of the above, the non-science classes need more urgent and stringent measures, if they must continue to study and do well in biology.

This study has also shown that difference in learning outcomes between male and female students was not significant, females performed slightly better than males. Hence, we should not rest on the achievement so far recorded in closing the gap between males and females in science education but should continue until the females could do as well as the male students. As much as possible Teachers should as far as possible follow their pursuit of encouraging more females into the study of biology.

Developed, in the light of the findings discussed so far in the paper, are the following recommendations:

1. It is particularly pertinent for teachers of biology to adopt Mercedes Model with Embedded Assessment Strategy and Technology in the teaching of students in Senior Secondary School.

2. Curriculum developers need to develop Mercedes Model with Embedded Assessment and Technology packages for all the concepts of biology including curricular and instructional resources and develop all tests and other measures of achievement accordingly.

3. The government should recommend the use of the strategy in the biology curriculum as well as other science subjects (Physics, Chemistry and Mathematics) in the secondary schools.

4. Mercedes Model with Embedded Assessment Strategy and Technology should be used for teaching both science and non-science students especially biology which in a distant future will still continue to be offered by most if not all students in the senior secondary schools.

5. Being especially adequate for public schools with large population of students, Mercedes Model with Embedded Assessment Strategy and Technology could be an invaluable tool for biology teachers in their attempts to find the best solutions to the problems arising from teaching in densely populated schools. 
6. Teacher Educators should include the Mercedes Model and Embedded Assessment Strategy and Technology as part of courses in methodology at the College of Education as well as Faculties of Education in Nigeria Universities.

\section{Conclusions}

It is noteworthy that Mercedes Model with Embedded Assessment and Technology as it has been used in this study has allowed teachers to teach for understanding and application and improved students' learning outcomes. Technology is revolutionarily affecting educational method universally and has impacted on the quality and quantity of teaching, learning and research in teacher education. Therefore, if we must become one of the 20 most industrialized nations in the world by 2020, if we have to meet the 2030 agenda for sustainable development (United Nations, 2015) and reduce the shortage of manpower in science and technology, then teachers are expected to use technology along with Mercedes Model with Embedded Assessment Strategy to present biology concepts for understanding and application.

\section{References}

Abimbade, A. (2014). In the Classroom: Implications for E-learning. $32^{\text {nd }}$ Proceedings of Nigeria Association for Educational Media and Technology (NAEMT), (pp. 6-8).

Achor, E. E. and Ukwuru, J. O. (2014). An Examination of the facilitative effect of the Computer Assisted Instruction (CAI) in Students' achievement in Chemical reaction and equilibrium. Education. 4.1:7-11.

Ahmed, M.A. (2008). Influence of personality factors on Biology lecturers' assessment of difficulty levels of genetics concepts in Nigerian colleges of education. An Unpublished Ph.D. thesis, University of Ilorin.

Ajewole, G. A. (1994). Effects of Guided Discovery and Expository Instructional Methods on the Attitude of Students to Biology. Journal of Research in Science Teaching, 28(5): 401-409.

Akubuilo, D. U. (1995). Effects of Problem-Solving Instructional Strategies on Students Achievement in Biology. An Unpublished Ph.D. Dissertation, Faculty of Education, Nsukka: University of Nigeria.

Briggs, J. (1988). Approaches to Learning and to Essay Writing: In R.R. Schmeck (ed.). Learning Strategies and Learning Styles (185-228). New York: Plenum.

Christianson, R.G, \& Fisher, K.M. (1999). Comparison of student learning about diffusion and osmosis in constructivist and traditional classrooms. International Journal of Science Eduation, 21, 687-698.

Erhan, D. and Okan, B. (2011). The relationship between students' exposure to technology and their achievement in Science and Mathematics. The Turkish online Journal of Educational Technology. 10

Esiobu, G. O. (2000). Biology Teacher Awareness and Level of use of Mental Analogies in Teaching Difficult Concept in Biology. 41st STAN proceedings 2000.

Federal Ministry of Education (FME). (2013). National Curriculum for Senior Secondary School Biology Lagos. Government Press. 
Federal Republic of Nigeria (2004). National Policy on Education, $4^{\text {th }}$ edition, NERDC Press, Yaba, Lagos, Nigeria.

Fisher, K.M., Williams, K.S., \& Lineback, J. (2011). Osmosis and diffusion conceptual assessment. CBE-Life Sciences Education 10, 418-429.

Gallagher, J. J. (2000). Teaching for Understanding and Application of Science Knowledge. School Science and Mathematics 100(6).

Giancarlo, C. A., \& Facione, P. A. (2011). A look across four years at the disposition toward critical Gough A. 2002. Mutualism: A different Agenda for Environmental and Science Education. International Journal of Science Education, 24, 1201-1215

Iroegbu, T. O. (1998). Problem-based Learning, Numerical Ability and Gender as Determinants Skill as Senior Secondary Physics in Ibadan. Unpublished Ph. D Thesis. Teacher Education Department. University of Ibadan.

James, T. and Shaibu, A. (1997). The Relative Effects of Inquiry and Lecture Methods on the Performance of High and Low Achievers in Senior Secondary School Biology. Journal of the Science Teacher's Association of Nigeria 32 (182): 59 - 64.

Muhammad, R. J. (2011). Globalization and human capacity building in higher education through information and communication technology. $32^{\text {nd }}$ Proceedings of Nigeria Association for Educational Media and Technology (NAEMT), 1-5.

Odom, A.L., \& Barrow, L.H. (1995). Development and application of a two-tier diagnostic test measuring college biology students' understanding of diffusion and osmosis after a course of instruction. Journal of Research in Science Teaching, 32, 45-61.

Odom, A.L., \& Barrow, L.H. (2007). High school biology students' knowledge and certainty about diffusion and osmosis concepts. School Science and Mathematics, 107, 94-101.

Ogundiwin O.A (2013); Effect of pre-theoretic intuition quiz and puzzle-based critical thinking motivation strategies on students learning outcomes in selected environment related concepts, in biology. Unpublished Ph.D. Thesis University of Ibadan. Pg. 38-40.

Ogundiwin, O.A. \& Oladipo, A.J. (2018). Effect of puzzle-based strategy on Senior Secondary School students' science process skills in Biology in Oyo state. Journal of Curriculum and Instruction. 11, (1) 26-36.

Oguntunde, A. S. (2014). Development and effect of two computer-based multimedia instructional packages on learning outcomes of colleges of education pre-service distance learning teachers. A Post-field Report presented at the Joint Staff/Higher Degree Students Seminar Series, Department of Teacher Education, Faculty of Education, University of Ibadan.

Okebukola, P. A. O. (2013). Saving Nigeria from itself: Towards a redemption plan for education. A $50^{\text {th }}$ Anniversary Lecture, Faculty of Education, University of Ibadan, Ibadan.

Oladipo, A.J. (2009). Enhancing senior secondary school students' cognitive achievement in selected Biology concepts using Mercedes Model with embedded assessment strategy. Unpublished Ph.D Thesis, Faculty of Education, University of Lagos

Oladipo, A.J., \& Ihemedu, C.M. (2018). Conceptual understanding of diffusion and osmosis among senior secondary school students in Lagos State. Journal of Science teachers Association of Nigeria.53,1-13. 
Popoola, A. A. (2011). Effects of simulation-games method on the achievement and attitude of junior secondary school students towards Mathematics. Educational thought. 8.1: 12 - 21

She, H.C. (2004). Facilitating changes in ninth grade students' understanding of dissolution and diffusion through DSLM instruction. Research in Science Education, 34, 503-525.

Solomon, J. (1994). The Rise and Fall of Constructivism. Studies in Science Education. 23:1-19.

Udeani, U. (2002). Assessing the Level of Science Process Skills Acquisition of Nigerian Senior Secondary School Students in Lagos State. African Journal of Curriculum and Instruction. 1(1):210-218.

Verhoeff, R. P. (2003). Towards Systems Thinking in Cell Biology Education, Coeur d'Alene Press, Utrecht, The Netherlands.

WAEC Chief Examiners' Reports (2000, 2003, 2005, 2006, 2012) The West African Senior School Certificate Examination May/June: Chief Examiners Reports Nigeria, Yaba, Lagos.

Welch, W. (1985). Secondary Analysis and National Assessment in Science in the U. S. A. In B. Frazer and K. G. Tobins (Eds.) Secondary Analysis and Large-Scale Assessment West Australia Institute of Technology. Berth.

Zuckerman, J.T. (1998). Representations of an osmosis problem. American Biology Teacher, 60, $27-$ 30. 